\title{
Centrum federalne wobec problemu aktywności międzynarodowej regionów w kontekście ewolucji stosunków federacyjnych w Rosji ${ }^{1}$
}

Streszczenie: Celem artykułu jest analiza federalno-regionalnego modelu stosunków w odniesieniu do międzynarodowej aktywności poszczególnych regionów. Uporczywy trend centralizacji modelu federalno-regionalnego, zapoczątkowany za prezydentury Władimira Putina, spowodował powstanie nietypowej koncepcji centralnej koordynacji międzynarodowymi działaniami regionów. Pomimo dominacji Federacji Rosyjskiej nad regionami, nie jest to koncepcja utrwalona, ponieważ Kreml nie dysponuje wystarczającymi zasobami, głównie personalnymi, aby w pełni kontrolować sytuację polityczną w regionach. Wyłaniająca się koncepcja centralizmu wydaje się nie tylko szkodzić interesom poszczególnych regionów, ale podważać także siłę putinowskiego reżimu autorytarnego w dalszej perspektywie.

Słowa kluczowe: centrum-regiony, Rosja, centralizacja, system polityczny Rosji

\section{Wstęp}

Droblem aktywności międzynarodowej podmiotów składowych Federacji Rosyjskiej (regionów) po roku 1999 - wyznaczającym schyłek dekady rządów Borysa Jelcyna - znacząco stracił na atrakcyjność w oczach środowiska politologicznego podejmującego badania nad współczesną Rosją. Nie oznacza to, że nie powstało po roku 1999 szereg interesujących opracowań w danym obszarze badań, tak w samej Rosji (Плотникова, 2005; Бусыгина, Лебедева, 2008), na Zachodzie czy w końcu w samej Polsce (Raś, 2013; Rychlik, 2014). Nie sposób jednak pod względem ilościowym porównywać zbioru publikacji w danym obszarze badań mających odniesienie do okresu rządów Jelcyna z tymi,

${ }^{1}$ Artykuł powstał w ramach realizacji projektu NCN OPUS 6, Panel HS5 Wymiary aktywności międzynarodowej władz regionalnych na przykładzie Chińskiej Republiki Ludowej, Republiki Indii i Federacji Rosyjskiej (kierownik projektu: dr hab. Małgorzata Pietrasiak). 
które podejmują problematykę współpracy międzynarodowej regionów w przypadku Rosji Władimira Putina (Chirikova, Lapina, 2001; Perović, 2000; Makarychev, 2000).

W przeciwieństwie do okresu lat 90. aktywność międzynarodowa rosyjskich regionów jest dziś mniej spektakularna, nie rozwija się tak dynamicznie i, co chyba najważniejsze, nie generuje takiego napięcia $\mathrm{w}$ relacjach z centrum federalnym - nie przyciaga więc zainteresowania badaczy. Jednak autorzy, którzy odnotowują spadek zainteresowania aktywnością międzynarodową rosyjskich regionów podkreślają, że jest ona „W dalszym ciagu istotnym zagadnieniem tak z punktu widzenia podmiotów składowych [Rosji - M. S.], jak i polityki zagranicznej realizowanej przez Moskwę" (Joenniemi, Sergunin, 2014, s. 19).

Przyjmując to założenie, można wskazać dwa bloki problemów, które wymagają szczególnej uwagi, jeśli chodzi o aktywność międzynarodową regionów Rosji po 1999 roku. Pierwszy z nich miałby charakter teoretyczno-metodologiczny (i zarazem komparatywny) i dotyczyłby m.in. porównania przesłanek i form aktywności międzynarodowej regionów w obu dekadach, drugi zaś podnosiłby kwestie praktyczne związane z ewoluującym stosunkiem centrum federalnego do aktywności regionów poza granicami Federacji Rosyjskiej i instytucjonalizacją określonego modelu relacji centrum-region w omawianym obszarze stosunków federacyjnych. Dany blok problemowy powinien zostać przeanalizowany z uwzględnieniem dostępnej wiedzy na temat ewolucji rosyjskiego modelu stosunków federacyjnych, tym bardziej że uległ on diametralnej przebudowie, do tego stopnia, że wielu autorów zaczęło kwestionować zasadność stosowania terminu federalizmu w odniesieniu do relacji łączących centrum i regiony (Захаров, 2008). Autor koncentruje się w niniejszym opracowaniu na bloku praktycznym aktywności międzynarodowej regionów, stojąc na stanowisku, że w stosunku do lat 90 . model relacji centrum-regiony w danym obszarze aktywności regionów uległ istotnej zmianie. Przyjmuje także, że koresponduje to ze zmianami, które dokonały się w Rosji po roku 1999 tak w sferze stosunków federacyjnych, jak i szerzej w ramach systemu politycznego. Należy bowiem założyć, że aktywność międzynarodowa regionów musiała ulec diametralnej zmianie, tak jak radykalnie zmienił się model rosyjskiego federalizmu, którego częścią była autonomia regionów na polu współpracy międzynarodowej.

W wymiarze metodologicznym autor wykorzystuje matrycę badawczą autorstwa Aleksandra Kuzniecowa, umożliwiającą przeprowadzenie całościowej analizy zjawiska aktywności międzynarodowej regionów 
i polityki rządu centralnego w odniesieniu do tegoż problemu, koncentrując się na jednym $z$ aspektów rzeczonego zjawiska (i elementów matrycy) i dotyczącego percepcji tejże aktywności przez centrum federalne z punktu widzenia interesu narodowego, polityki centrum federalnego wobec międzynarodowej współpracy regionów (Kuznetsov, 2015, s. 116). Autor stara się podjąć próbę odpowiedzi na pytanie z jakim modelem relacji centrum-regiony w odniesieniu do aktywności międzynarodowej regionów mamy do czynienia w Rosji po 1999 roku, a także czy ten kształtujący się model cechuje się jakimś wewnętrznym zróżnicowaniem, tak jak to miało miejsce w okresie lat 90.

Podnosząc problem instytucjonalizacji szczególnego modelu relacji centrum-regiony $\mathrm{w}$ odniesieniami do zjawiska paradyplomacji rosyjskich regionów na tle ewolucji stosunków federacyjnych autor chce zwrócić uwagę, że specyficzne podejście elit federalnych do problemu suwerenności Rosji i autonomii regionów, w tym także w zakresie ich aktywności międzynarodowej, może zostać „obarczone winą” za wykształcenie się w omawianym obszarze stosunków federacyjnych określonego modelu relacji.

Na całość ewolucji polityki centrum federalnego wobec aktywności międzynarodowej regionów Rosji, tak w ujęciu konceptualnym (model myślenia elit federalnych), jak i praktycznym (zbiór rozwiązań prawnych i rzeczywistych działań wobec regionów), należy spojrzeć przez pryzmat szkoły realizmu w nauce o stosunkach międzynarodowych. Pozwoli to lepiej zrozumieć szczególne podejście do „paradyplomacji” we współczesnej Rosji, tym bardziej, że realizm silnie obecny jest w rosyjskim dyskursie naukowym i politycznym, czego dowodem jest dominująca w Rosji tendencja do afirmowania roli państwa w stosunkach międzynarodowych, obdarzania szczególnym stosunkiem takich pojęć jak suwerenność, interes narodowy, strefy wpływów i geopolityczne centra siły (Leichtova, 2015, s. 21-26; Lo, 2002, s. 103-118). W takim ujęciu, realizm mający odniesienie przede wszystkim do sfery aktywności międzynarodowej państwa, odciska swe piętno na polityce wewnętrznej Rosji, w tym przypadku na modelu stosunków federacyjnych.

\section{Ewolucja stosunków federacyjnych w Rosji}

Problem instytucjonalizacji aktywności międzynarodowej podmiotów składowych Federacji Rosyjskiej w latach 1991-2015 i stosunku centrum federalnego do tego zjawiska są ściśle powiązane $\mathrm{z}$ ewolucją federali- 
zmu w Rosji, a dokładniej rzecz biorąc z przemianami mającymi miejsce w obrębie systemu stosunków centrum-regiony.

Przyjmując za główne kryterium zbiór kluczowych tendencji mających miejsce w obrębie systemu stosunków centrum-regiony, wyszczególnia się dwa zasadnicze etapy rozwoju federalizmu w Rosji: etap decentralizacji (1990-1999) i centralizacji (od 2000). Jeśli pokusić się o bardziej szczegółowy i zarazem pogłębiony model analizy stosunków federacyjnych, uwzględniający np. problem asymetrii, konsekwencji wysiłków centralizacyjnych Kremla i teorii federalistycznych, otrzymamy 3 okresy: 1) okres parady suwerenności 1990-1993; 2) okres asymetrycznego federalizmu 1993-1999; 3) okres unitarnego federalizmu od $2000 \mathrm{r}$.

Pierwszy okres związany jest z rozpadem Związku Radzieckiego i ,paradą suwerenności”, będącą procesem gwałtownego i niekontrolowanego dążenia przez podmioty składowe (głównie republiki) Rosji do większej autonomii, będącej pokłosiem walki pomiędzy Borysem Jelcynem i Michaiłem Gorbaczowem.

W drugim okresie, określanym mianem asymetrycznego federalizmu zasady relacji centrum-regiony miały wytyczać normy Konstytucji, zaś sam federalizm miał mieć charakter konstytucyjny nie zaś traktatowy. Regiony skorzystały skwapliwie z konstytucyjnych możliwości ustanawiania własnego modelu systemu władzy. Instytucja wyborów najwyższych osób urzędowych zawitała na rosyjską prowincję. W praktyce ziścił się „czarny scenariusz” próby połączenia procesów federalizacji i demokratyzacji systemu politycznego. Elity regionalne ustanowiły w szeregu regionach systemy autorytarne, skorumpowały federalnych urzędników w regionach, wymknęły się centrum spod kontroli. Znacząca asymetria strukturalna cechująca podmioty składowe Rosji (w tym dysproporcje w rozwoju społeczno-gospodarczym) odcisnęła swe piętno na rosyjskim federalizmie - regiony różniły się pomiędzy sobą, różne były więc ich relacje $\mathrm{z}$ centrum.

Po roku 1999, a dokładniej z chwilą wyboru Władimira Putina na stanowisko Prezydenta Rosji w marcu 2000, rozpoczyna się okres trzeci, którego cechą charakterystyczną jest ustanowienie modelu unitarnego federalizmu. W roku 2000 rozpoczął się proces odbudowy jedności konstytucyjno-prawnej przestrzeni Rosji - dokonującej się pod hasłem „dyktatury prawa”, w ramach którego miało miejsce ograniczenie wpływu regionów na proces decyzyjny szczebla federalnego (włączając w to zmianę zasad wyboru członków Rady Federacji) i regionalnego (wyeliminowanie powszechnych wyborów najwyższych osób urzędowych 
w podmiotach składowych Federacji Rosyjskiej). Wzmocniono zakres kontroli nad regionami w ramach programu budowy ,pionowo zintegrowanej struktury władzy wykonawczej" poprzez ustanowienie instytucji pełnomocnego przedstawiciela Prezydenta FR w okręgu federalnym obejmującym kilka-kilkanaście regionów, ,penetracji” regionalnych systemów politycznych przez kremlowską ,partię władzy”, wprowadzenia zakazu funkcjonowania partii regionalnych i odpowiedniego uposażenia pracowników federalnych agencji w regionach. Nastąpił w końcu proces przeniesienia części regionalnych zakresów działania i kompetencji w stronę centrum federalnego. Rozwiązano także umowy dwustronne centrum-regiony o rozgraniczeniu zakresów działania i kompetencji, zawierane przez cały okres lat 90 . Zastapił je zbiór ustaw federalnych precyzujących zapisy konstytucyjne mówiące o kompetencjach wspólnych federacji i podmiotów (Стародубровская, Глазычев, 2011). Ze względu na daleko idącą rozbieżność pomiędzy formalno-prawnym zakotwiczeniem federalizmu w Rosji i codzienną praktyką federalistyczną (a raczej jej brakiem), połączoną z brakiem gotowości Kremla do formalnego wyeliminowania z tekstu konstytucji norm świadczących o federalnym charakterze państwa, przyjmuje się określać Rosję mianem „federacji bez federalizmu". Jeśli natomiast wziąć pod uwagę fakt, że rosyjskie władze próbują pogodzić dobrodziejstwa federalizmu z praktyką państwa unitarnego, staje się zrozumiałe, że federalizmowi we współczesnej Rosji przypisuje się również termin „unitarny” (Захаров, 2008, s. 114-116).

\section{Miejsce i rola autonomii elit regionalnych w sferze aktywności międzynarodowej w myśleniu elit federalnych Rosji}

Aby lepiej zrozumieć ewolucję relacji centrum-regiony w odniesieniu do problemu zaangażowania rosyjskich regionów we współpracę międzynarodową należy poznać główne wątki myślenia przedstawicieli rosyjskiej elity politycznej szczebla federalnego w odniesieniu do takich pojęć jak: suwerenność, globalizacja/glokalizacja, i „paradyplomacja”.

Rosyjskie centrum federalne uosabiane przez jego elity polityczne - w szczególności związane z resortami siłowymi - jeszcze w latach 90. miało chłodny stosunek do wszelkich działań, które mogłyby poskutkować naruszaniem rosyjskiej suwerenności. W związku z tym „kohorta siłowa" rosyjskiej elity federalnej odpowiedzialna za kształtowanie rosyjskiej polityki zagranicznej i bezpieczeństwa postrzegała globalizację 
z dużą podejrzliwością. W późniejszym okresie - głównie pod wpływem przypadków zaangażowania Zachodu w proces instalacji rozwiązań demokratycznych w państwach ich pozbawionych i interwencji humanitarnych - została odrzucana jako niedopuszczalna koncepcja „ograniczonej suwerenności” (Макарычев, 2001).

Samą globalizację uznawano za narzędzie, przy pomocy którego Stany Zjednoczone i ich sojusznicy próbują poddać Rosję geopolitycznej dominacji. Centralizacja władzy - w rozumieniu odebrania regionom szeregu funkcji władczych, w tym także w sferze aktywności międzynarodowej wydawała się być z takiej perspektywy działaniem korzystnym, wzmacniającym stan bezpieczeństwa narodowego Rosji. Pozwalała oddalić groźbę poddania Rosji kontroli któremuś z geopolitycznych centrów siły (Макарычев, 2001).

Na cenzurowanym znalazła się w końcu także glokalizacja. Aktywność międzynarodowych organizacji pozarządowych na szczeblu regionalnym w Rosji zaczęto uznawać za zagrożenie z punktu widzenia bezpieczeństwa narodowego i przypisywać im odpowiedzialność za destabilizację pokoju na świecie. Zaangażowanie organizacji pozarządowych w wydarzenia polityczne w Ukrainie, a wcześniej także w Gruzji potraktowano w najwyższych kręgach władzy Rosji niezwykle poważnie i podjęto szereg działań prewencyjnych na okoliczność rozprzestrzeniania się „pomarańczowego wirusa” (Ambrosio, 2009, s. 45-53). Zabezpieczanie rosyjskiego systemu politycznego przed egzogenną promocją demokracji doprowadziło m.in. do przyjęcia ustawodawstwa „o obcych agentach wpływu", ograniczającego możliwość współpracy także na poziomie regionalnym pomiędzy rosyjskimi organizacjami pozarządowymi a zagranicznymi donatorami (Никольская, Романычева, 2015).

W literaturze przedmiotu przywoływanych jest szereg wypowiedzi urzędników federalnych dowodzących istnienia (i zakorzenienia się) w środowisku federalnych elit Rosji tzw. „strategicznej kultury myślenia”, której cechą charakterystyczną była i jest niechęć do nadmiernej autonomii regionów, w tym także w sferze aktywności międzynarodowej. $\mathrm{Na}$ szczególną uwagę zasługuje wywiad jakiego w roku 1999 udzielił wysoki urzędnik rosyjskiego ministerstwa spraw zagranicznych odpowiedzialny za współpracę z regionami - Eduarda Kuzmina (Every Village, 1999). Twierdził on m.in., iż zagraniczni konkurenci Rosji nie są zainteresowani integralnością Rosji. Niektóre mocarstwa, w myśl jego słów, nie szczędzą wysiłków i zasobów, aby uzyskać od rosyjskich regionów szereg przywilejów i omijając centrum federalne tworzyć „międzynarodowe strefy 
przyciagania". Zarzucił on także obcym (tj. zachodnim) państwom tendencję do uzależniania rosyjskich regionów w wymiarze surowcowym, finansowym, technologicznym, zwiększanie ich zadłużenia zagranicznego, zbijanie cen na towary eksportowe i w końcu wprowadzanie zamętu w rosyjskim społeczeństwie (Every Village, 1999). Wszystko to dawało podstawę do zajęcia przez centrum co najmniej ostrożnego stosunku w odniesieniu do aktywności międzynarodowej rosyjskich regionów, ze względu na przeświadczenie o złych intencjach ze strony aktorów zewnętrznych, z którymi współpracowały rosyjskie regiony.

Część komentatorów odnotowywało, że już w okresie poprzedzającym objęcie władzy w Rosji przez Władimira Putina, rosyjskie centrum federalne miało co najmniej ambiwalentny stosunek do aktywności międzynarodowej regionów. Z jednej strony rosyjski MSZ cieszył np. fakt przyciagania przez regiony zagranicznych inwestycji i podtrzymywania kontaktów z etnicznymi Rosjanami (russkimi) w państwach obszaru poradzieckiego, z drugiej zaś strony niepokoił fakt wypaczania przez regionalną ,paradyplomację” przekazu rosyjskiej polityki zagranicznej, czy wręcz wspierania tendencji odśrodkowych i separatyzmu w Rosji (Every Village, 1999). Nawet tak pozytywne aspekty regionalnej aktywności międzynarodowej, jak przyciaganie inwestycji zagranicznych miało swe cienie, bowiem rosyjskie regiony rywalizowały o nie ze sobą, w sposób który przynosił straty całej Rosji. Zdecydowaną akceptację w oczach centrum federalnego zyskiwała natomiast współpraca przygraniczna z państwami WNP, pomagać miała ona chronić prawa Rosjan w tych państwach i stymulować procesy integracyjne w regionie. Afirmowano ten rodzaj aktywności regionów, bowiem postrzegano ją w kategoriach rozwinięcie polityki zagranicznej Rosji (Every Village, 1999).

Brak ścisłej koordynacji działań pomiędzy centrum i regionami, sprzyjał podejmowaniu przez te ostatnie działań i deklaracji, które narażały na szwank interesy i wysiłki Moskwy, czy to w odniesieniu do relacji z Tajwanem, czy w stosunkach z Organizacją Narodów Zjednoczonych i jej agendami. Rozwój „paradyplomacji” miał stymulować narastanie tendencji separatystycznych - szereg republik zdecydowanie przekroczyło w swych działaniach normy konstytucyjne i żądało dla siebie praw do realizacji własnej polityki zagranicznej w kwestiach wojny i pokoju, stref nuklearnych i w innych obszarach zarezerwowanych dla Moskwy. Ten rodzaj postawy miał mieć niebezpiecznie zaraźliwy wpływ na inne regiony. „Jak tak dalej pójdzie, to każda wieś będzie miała swoje ministerstwo spraw zagranicznych", mówił Kuzmin (Every Village, 1999). 
Cytowany urzędnik posunął się do tego, że połączył problem kryzysu, w jakim w latach 90. znalazła się rosyjska państwowość z aktywnością międzynarodową rosyjskich regionów i uzależnił jego przezwyciężenie m.in. od ukrócenia szkodliwej dla Rosji samowoli regionów.

\section{Praktyczny wymiar refleksji na temat autonomii regionów Rosji w sferze aktywności międzynarodowej}

Rosyjscy autorzy analizujący problem aktywności międzynarodowej regionów przed i po roku 2000 formułowali opinie, że nastrojom ambiwalencji po stronie centrum, w odniesieniu do tego aspektu funkcjonowania rosyjskiego federalizmu, towarzyszyły próby marginalizacji znaczenia regionów z punktu widzenia funkcjonowania polityki zagranicznej rosyjskiego państwa. Wynikało to jak już wiemy z przeświadczenia będącego udziałem elit federalnych Rosji, że wszystko co jest związane z bezpieczeństwem i/lub polityką zagraniczną jest i powinno pozostać wyłączną domeną centrum federalnego.

Andriej Makaryczew wskazywał m.in. na brak jakiejkolwiek wzmianki przed 2001 rokiem, w kluczowych z punktu widzenia bezpieczeństwa narodowego Rosji dokumentach, jak doktryna wojenna czy koncepcja polityki zagranicznej, o roli regionów na arenie międzynarodowej. Również późniejsze odsłony tych dokumentów milczą o udziale regionów w polityce zagranicznej Rosji (Макарычев, 2001). Warto też zwrócić uwagę na degradację i marginalizację tej formy aktywności regionów przez Ministerstwo Spraw Zagranicznych. Informacje na temat współpracy międzynarodowej i współpracy gospodarczej regionów Rosji z zagranicą na stronie rosyjskiego Ministerstwa Spraw Zagranicznych znajdziemy dopiero na podstronie „dyplomacja ekonomiczna” (Международные).

Rościsław Turowski zwraca uwagę, że niechęć centrum do ułatwiania regionom i jednostkom samorządu terytorialnego aktywności międzynarodowej była doskonale widoczna chociażby na przykładzie problemów związanych z przyjęciem ustawy o współpracy transgranicznej, co wynikać miało z etatystycznej wizji realizacji rosyjskiej polityki zagranicznej, zakładającej, że międzynarodowa współpraca regionów jest co prawda dopuszczalna, ale musi się odbywać przy obowiązkowej kontroli ze strony państwa (Туровский, 2011, s. 103). Centrum federalnemu nie zależało na ułatwianiu regionom rozwoju współpracy międzynarodowej, poprzez ustanawianie prostych i czytelnych reguł odnośnie do współpracy przy- 
granicznej (transgranicznej). Taka współpraca miała się odbywać tylko w oparciu o takie zasady, które korespondowałyby z interesami całego państwa (tj. Kremla) i gwarantowałyby realizację celów sformułowanych przez państwo.

Tego rodzaju etatystyczne podejście do ,paradyplomacji” jest w chwili obecnej w Rosji realizowane w praktyce i stanowi m.in. pochodną zmian, jakie dokonały się w strukturze elit politycznych Rosji po 1999 roku. Choć należy mieć świadomość, że już w latach 90. tendencja do podporządkowywania interesom państwa aktywności regionów była bardzo silnie zarysowana w myśleniu przedstawicieli elit federalnych Rosji. W szerszej perspektywie dyskursu politycznego warto zwrócić uwagę, że „liberalne” i pro-zachodnie podejście w polityce zagranicznej rosyjskiego państwa $\mathrm{z}$ trudem maskowało silną tendencję myślenia w kategoriach realizmu (Leichtova, 2015, s. 21).

Wraz z objęciem urzędu prezydenckiego przez Władimira Putina - pułkownika Federalnej Służby Bezpieczeństwa (FSB), szeregi elit politycznych, biznesowych i administracyjnych zaczęli masowo zasilać „ludzie w pagonach”. W związku z tym etatystyczny model polityki zagranicznej zaczął się dynamicznie rozwijać.

Rosnące znaczenia FSB, sprzyjało umacnianiu się pozycji Federalnej Służby Granicznej, która wróciła „na łono” FSB. Jej ,interesy” postawiono wyżej od potrzeb lokalnych wspólnot - w szczególności tych przygranicznych. Przykładem tego typu działania było rozszerzenie obszaru obowiązywania reżimu strefy granicznej. Regulacje w tym zakresie przede wszystkim pozostają w zakresie wspólnego działania centrum i regionów. Tym nie mniej w roku 2004 dokonana została modyfikacja ustawy o granicy państwowej, która pozwala FSB - bez konsultacji z regionami - zmieniać zasady rządzące strefą przygraniczną. Usunięty został zapis ograniczający zasięg oddziaływania strefy do 5 kilometrów. W konsekwencji w niektórych regionach rozciąga się ona na głębokość 60 kilometrów, oczywiście regulacje w odniesieniu do niej nie są surowo przestrzegane, kontrole są rzadkie, a brak przepustki wydawanej przez regionalne oddziały FSB karany jest niedużymi karami, fakt pozostawał faktem, jak zauważał Turowski, daje się bowiem zauważyć tendencję, do postrzegania strefy przygranicznej w charakterze obszaru zagrożenia, wymagającego szczególnej uwagi i ograniczenia swobód obywatelskich (w tym przypadku swobody przemieszczania się). Strefa przygraniczna nie jest rozpatrywana w kategoriach strefy współpracy (Туровский, 2011, s. 103). 
W procesie instytucjonalizacji prawnej aktywności międzynarodowej regionów, który rozpoczął się w połowie lat 90 . wypracowany został ostatecznie taki model relacji, który w pełni satysfakcjonował centrum. Korespondował bowiem z jego obawami i uprzedzeniami co do nadmiernej i pozbawionej kontroli autonomii regionów, a także koordynującej roli centrum z punktu widzenia ich współpracy międzynarodowej. Po roku 2000 pojawiło się szereg dalszych normatywnych aktów, które umacniały zasadę koordynacji przez centrum aktywności międzynarodowej regionów (Намчак, 2012, s. 76-78). Można do nich zaliczyć m.in. rozporządzenie o przedstawicielstwie rosyjskiego Ministerstwa Spraw Zagranicznych na terenie Federacji Rosyjskiej z 2002 roku i z późniejszymi jego modyfikacjami, np. w postaci rozporządzenia o organie terytorialnym - przedstawicielstwie MSZ FR na terytorium FR z 22 listopada 2011 roku (Положение, 2011). Rozporządzenie o którym mowa, nakładało na regionalne przedstawicielstwo MSZ zadanie zapewnienia poszanowania zasady spójności polityki zagranicznej FR i kontroli realizacji zasady ogólnej koordynacji aktywności międzynarodowej podmiotów składowych FR (Положение, 2011).

Rozwiązania prawno-instytucjonalne w sferze aktywności międzynarodowej regionów spotykały się z pozytywnymi reakcjami w środowisku politologicznym. Wskazywano m.in., że uregulowanie na szczeblu federalnym aktywności międzynarodowej regionów przyczyniły się do tego, że aktywność ustawodawcza podmiotów „stała się bardziej przemyślana i poprawna z punktu widzenia ich zgodności z ustawodawstwem federalnym". To samo tyczyło się także umów zawieranych z partnerami zagranicznymi - stały się one bardziej konkretne, usystematyzowaniu uległy zasady regulujące procedury związane z otwieraniem przedstawicielstw podmiotów za granicą (Rychlik, 2014, s. 277-278). Z drugiej strony, instytucjonalizacja prawna aktywności międzynarodowej regionów na szczeblu federalnym, doprowadziła do znacznego ograniczenia autonomii regionów w tym wymiarze funkcjonowania rosyjskiego federalizmu. Co więcej, szeregu kwestii związanych ze współpracą międzynarodową regionów nie zdołano uregulować. Najlepszym przykładem może być brak prawnego uregulowania zasad współpracy przygranicznej (transgranicznej) z udziałem regionów Rosji i jednostek samorządu terytorialnego, pomimo wieloletnich prób w tym zakresie podejmowanych zarówno przez zainteresowane regiony, jak i izbę regionów, tj. Radę Federacji (Europejska, 1980; Доклад, 2010). 


\section{Dwa modele relacji centrum-regiony w zakresie aktywności międzynarodowej regionów Rosji}

Próbując udzielić odpowiedzi na pytanie, z jakim modelem relacji centrum-regiony mamy do czynienia w Rosji, w odniesieniu do sfery aktywności międzynarodowej tych ostatnich, natknąć można się na szereg poważnych wyzwań badawczych. Są one m.in. związane z dostępnością miarodajnych informacji - szczególnie po 2000 roku - w odniesieniu do faktycznego kształtu rozwoju współpracy międzynarodowej regionów, a także zakresu kontroli i koordynacji podobnych działań ze strony centrum federalnego. Należy także zauważyć, że dywersyfikacja społeczno-gospodarcza, polityczna i etniczna będąca „wizytówką” rosyjskiego (asymetrycznego) federalizmu odcisnęła swoje piętno również na sferze aktywność międzynarodowej regionów i ich relacjach z centrum federalnym w całym okresie lat 90 . Dywersyfikacja relacji między centrum a regionami w odniesieniu do aktywności międzynarodowej tych ostatnich była wypadkową potencjału regionów, ich ekonomicznej i politycznej „wagi” - głębokie dysproporcje w rozwoju społeczno-gospodarczym regionów Rosji wciąż dają o sobie znać (Неяскин, 2015). W konsekwencji, przed 2000 rokiem, kształt relacji centrum-regiony w zakresie współpracy międzynarodowej miał silnie zindywidualizowany charakter.

W pierwszym okresie tj. przed 2000 rokiem, w stosunkach pomiędzy Kremlem a władzami regionów obecnych było szereg modeli relacji w sferze aktywności międzynarodowej regionów. Wynikało to bowiem zarówno z uwarunkowań formalnych (np. z treści umów dwustronnych centrum-region), jak i faktycznych (zawłaszczanie kompetencji centrum przez region). Aktywność międzynarodowa rosyjskich regionów pozostawała zróżnicowana, tak jak zróżnicowane były rosyjskie regiony i ich relacje z centrum. Asymetria w relacjach pomiędzy regionami, a także pomiędzy centrum i regionami - jak zostało to już wspomniane - nie omijała również obszaru aktywności międzynarodowej. Dominował jednak model zdecentralizowanej i równoległej praktyki współpracy międzynarodowej centrum i regionów. Sytuacji nie zmieniło przyjęcie w roku 1995 i 1996 ustaw federalnych i prezydenckiego dekretu regulującego wzajemne stosunki w sferze aktywności międzynarodowej regionów, chociaż powinien zacząć obowiązywać model scentralizowanej kooperacji centrum i regionów, koordynowany przez centrum federalne.

W niektórych przypadkach miał on charakter harmonijnej współpracy (centrum wspierało działania regionów - Niżny Nowgoród) (Chirikova, 
Lapina, 2001, s. 44), w niektórych - głośnych - przypadkach mieliśmy do czynienia z sytuacjami konfliktowymi tzn. regiony angażowały się we współpracę międzynarodową, np. zabierały głos na forach międzynarodowych w sprawach polityki międzynarodowej z pogwałceniem oficjalnego stanowiska i interesów rządu federalnego. Lista ,skandali” dyplomatycznych, naruszania interesów Rosji - rozumianych w tym przypadku jako niezgodność poczynań władz regionalnych z oficjalnym stanowiskiem Kremla - w latach 90. była długa. Przodowały w nich te regiony, które cieszyły się szczególnym statusem i mogły pozwolić sobie na niesubordynację, jak chociażby Tatarstan, lub miały świadomość całkowitej bezkarności swych działań (Makarychev, 1999, s. 504-506). Aktywność międzynarodowa - często realizowana wbrew interesom Kremla, naruszająca autorytet władz federalnych, delegitymizujących jego działania i podjęte zobowiązania międzynarodowe służyła budowie politycznego kapitału niektórych z przedstawicieli elit regionalnych. Sztandarowymi przykładami takich polityków byli: Jewgienij Nazdratenko i Jurij Łużkow, choć i Borysowi Niemcowowi zdarzało się ,rugać” Kreml za zbyt szczodrą i uległą politykę wobec białoruskiej dyktatury Aleksandra Łukaszenki, która nie odpowiada interesom Rosji (Makarychev, 1999, s. 504-505; Chirikova, Lapina, 2001, s. 43).

W niektórych przypadkach konflikty na linii centrum-regiony rozwiązywano na „korzyść” centrum, jak w przypadku obwodu kaliningradzkiego i jego umowy handlowej z Litwą, którą w 1995 roku anulowano ze względu na niezgodność z ustawodawstwem federalnym. W wielu przypadkach konflikty na linii region-centrum wynikały z faktu, że treść umów z połowy lat 90. nie była uzgadniania z MSZ - co w oczywisty sposób budziło niezadowolenie władz federalnych. Tak było chociażby w przypadku umowy pomiędzy Kabardyno-Bałkarią a Abchazją, będącą formalnie częścią Gruzji. W wielu innych sytuacjach problem niezgodności umowy z ustawodawstwem federalnym wynikał z niedopełniania wymogów technicznych związanych z jej przygotowaniem i dotyczył braku ekspertyz prawnych federalnego MSZ (Joenniemi, Sergunin, 2014, s. 23). W przypadku Tatarstanu kontrowersyjne i sprzeczne z interesem Kremla umowy np. z Abchazja, nie były rozwiązywane (Sharafutdinova, 2005, s. 394).

$\mathrm{W}$ drugim okresie tj. po 2000 roku wraz z początkiem budowy unitarnego federalizmu i wyborczego autorytaryzmu rozpoczyna się faktyczna instytucjonalizacja modelu scentralizowanej koordynacji działań centrum i regionów w sferze aktywności międzynarodowej tych drugich. W chwili obecnej mamy do czynienia w relacjach centrum-regiony z modelem 
scentralizowanego podejmowania decyzji w zakresie polityki regionalnej, zakładającym zasadę ścisłej koordynacji działań w sferze międzynarodowej z udziałem regionów i wymuszonej kooperacji.

Centrum federalne pod wpływem doświadczeń wyniesionych z obserwacji negatywnych skutków niekontrolowanej decentralizacji w okresie lat 90. rozpoczęto z inicjatywy Władimira Putina zdecydowane działania na rzecz odebrania regionom pochopnie przyznanych uprawnień i/lub zdobytych przez nie w porządku jednostronnym. W programie centralizacji kontynuowano wysiłki na rzecz dalszej instytucjonalizacji prawnej „paradyplomacji” utrzymanej w duchu scentralizowanej koordynacji. Koncepcja centrum federalnego w omawianym aspekcie stosunków federacyjnych zakładała uporządkowanie „chaotycznego środowiska” w sferze polityki zagranicznej, które wykształciło się w Rosji w wyniku aktywności międzynarodowej szeregu rosyjskich regionów, m.in. poprzez należyte spożytkowanie aktywności regionów, tak by wspierały one politykę zagraniczną Rosji, reprezentującą interesy całego państwa (Кониеепиия, 2010).

Mimo szeregu wątpliwości i zastrzeżeń co do jednostronnego charakteru relacji Kreml-elity regionalne po 2000 roku (o czym więcej w dalszej części opracowania) należy przyjąć, że dotychczas (względnie) samodzielni, i co ważniejsze, pochodzących z wyborów powszechnych, prezydenci i gubernatorzy podmiotów składowych Federacji Rosyjskiej, stali się zakładnikami woli Kremla (a biorąc pod uwagę formalny podział zakresów działania centrum-regiony wręcz ,agentami rządu federalnego”). Jeśli więc Jurij Łużkow lub któryś z innych szefów regionów zajmował stanowisko w kwestii spraw międzynarodowych, to z całą pewnością nie działo się to bez wiedzy i aprobaty Kremla. Po roku 2000 wszelkiego rodzaju ,polityczne swawole” na arenie międzynarodowej, z których znany był właśnie chociażby np. Łużkow - wypowiedzi na temat Ukrainy i Gruzji podważające ich integralność terytorialną - albo ustały, albo musiały mieć „cichą dyspensę” Kremla (Kurilla, 2006, s. 4).

\section{Dywersyfikacja modelu scentralizowanej koordynacji w relacjach centrum-regiony w odniesieniu do współpracy międzynarodowej regionów}

Przyjmując założenie, że po roku 2000 konsekwentnie postępuje w Rosji proces instytucjonalizacji modelu scentralizowanej koordynacji 
współpracy centrum i regionów w wymiarze „paradyplomacji”, należy zwrócić uwagę, że jest on wewnętrznie zróżnicowany, a więc nie uległ konsolidacji. Zróżnicowanie, o którym mowa, ujawnia się, kiedy padają następujące pytania: 1. czy centrum zdołało skutecznie i całkowicie podporządkować sobie regiony? oraz 2. czy w przypadku pozytywnej odpowiedzi na pierwsze z postawionych pytań, w ramach modelu pełnej kontroli ze strony centrum nad regionami obowiązuje jeden uniwersalny model tychże relacji?

$\mathrm{Z}$ całą pewnością jest wiele prawdy w stwierdzeniu, że centrum podporządkowało sobie regiony, w tym także ich „politykę zagraniczną”. Proces przebudowy systemu stosunków federacyjnych (i ich centralizacja), obejmujący wtłoczenie regionów w tzw. ,pionową strukturę władzy" doprowadził do drastycznego zmniejszenia znaczenia aktywności międzynarodowej regionów. W praktyce aktywność międzynarodowa nie tyle uległa zmniejszeniu, co raczej zmienił się jej charakter tak, że koresponduje on w chwili obecnej z modelem unitarnego federalizmu i wyborczego autorytaryzmu (Kuznetsov, 2009).

Regionalna aktywność na arenie międzynarodowej odbywa się w ścisłej współpracy z centrum. Kreml nie tylko nadzoruje aktywność władz regionalnych na arenie międzynarodowej, ale jest także promotorem ich współpracy międzynarodowej. Doskonałą ilustracją mechanizmów rządzących rosyjską paradyplomacją w regionie Dalekiego Wschodu jest Program wspótpracy między regionami Dalekiego Wschodu i Wschodniej Syberii Federacji Rosyjskiej a Pólnocnym Wschodem Chińskiej Republiki Ludowej na lata 2009-2018. Wspomniany program nie tylko miał zdynamizować współpracę międzynarodową regionów rosyjskiego Dalekiego Wschodu (znacznie odbiegającą pod względem swej dynamiki od innych regionów Rosji), ale także wesprzeć rządowy program modernizacji Dalekiego Wschodu, który to region pogrążał się w zapaści, podlegał depopulacji, jego mieszkańcy cierpieli z powodu przerw w dostawach energii i ogrzewania, pomimo strategicznego znaczenia, jakie przypisywał mu Kreml w procesie integracji geoekonomicznej Rosji z państwami regionu Północno-Wschodniej Azji (Makarov, Barabanov, Bordachev, Kanaev, Larin, Ryzhkov, 2014, s. 6-7). Przygotowanie i realizacja programu stanowi także egzemplifikację wielu negatywnych aspektów trapiących scentralizowane podejście do prób animacji współpracy międzynarodowej regionów. Jednocześnie jego dotychczasowe rezultaty stanowią przykład istnienia silnej rozbieżności interesów pomiędzy Chinami i Rosją w sferze współpracy gospodarczej (Программа, 2008; Информация, 2014). 
Przede wszystkim godzi się wspomnieć, że Program wspótpracy mający nadać dynamiki kontaktom pomiędzy regionami obydwu państw, został zaaranżowany na poziomie centralnym i patrząc z rosyjskiej perspektywy, podporządkowany został realizacji zadań, które wcześniej sformułował rosyjski rząd federalny, tj. wspomagania realizacji polityki regionalnej w ramach programu Rozwój gospodarczy i społeczny Dalekiego Wschodu i Zabajkala. Wyraźnie i silnie zaakcentowany został inwestycyjny i infrastrukturalny charakter programu - rozwój przejść granicznych i połączeń z Chinami jest bowiem uznawany za priorytetowy z punktu widzenia intensyfikacji wymiany towarowej Rosji z Chinami, w chwili obecnej absolutnie niewystarczalny i niewspółmierny do długości granicy pomiędzy oboma państwami. Zapaść infrastrukturalna rosyjskiego Dalekiego Wschodu blokuje wzrost dynamiki wymiany towarowej z Azją Północno-Wschodnią (Российско-китайский, 2015, s. 15). Organem koordynującym realizację Programu wspótpracy po stronie rosyjskiej miało być Ministerstwo Rozwoju Gospodarczego FR. Innymi słowy, rosyjski rząd federalny postanowił sięgnąc po pomoc ze strony Chin w celu rozwiązania własnych problemów i zobowiązań, przedstawiając to jako działanie na rzecz rozwoju współpracy przygranicznej regionów Rosji i Chin (Информация, 2014).

Po 2000 roku rosyjskie regiony są dość często instrumentalnie wykorzystywane przez władze centralne. Zakres formalnych pełnomocnictw władz regionalnych jest ograniczony i ma charakter wspomagający, tym nie mniej gubernatorzy i/lub przedstawiciele władz regionalnych są włączani w skład rosyjskich oficjalnych zagranicznych delegacji rządowych. Terytorium regionów (najczęściej przygranicznych), jest wykorzystywane jako miejsce spotkań i konsultacji międzypaństwowych w formacie państwo-państwo niekiedy nawet bez udziału władz samego regionu. Realizacja współpracy międzynarodowej przez Kreml z wykorzystaniem terytorium regionów, bez ich bezpośredniego udziału, stała się powszechną praktyką, bez względu na to czy mowa o współpracy z Kazachstanem czy Japonią (Туровский, 2011, s. 100-101).

Aktywność regionów jest w praktyce koordynowana i/lub stymulowana przez nowe agendy rządu federalnego, powstałe na fali centralizacji stosunków federacyjnych, w postaci pełnomocnego przedstawiciela prezydenta FR w okręgu federalnym. Biuro pełnomocnego przedstawiciela prezydenta FR w uralskim okręgu federalnym odpowiada m.in. za zorganizowanie międzynarodowych prezentacji regionów Uralu i Zachodniej Syberii. Kuzniecow zwraca uwagę, że część regionów celowo podkreśla 
kluczową rolę centrum federalnego jako animatora przedsięwzięć międzynarodowych z udziałem regionu. Przywołuje m.in. przykład obwodu swierdłowskiego i jego współpracy z Bawarią, która to współpraca miała stanowić logiczną kontynuację udziału gubernatora obwodu - Eduarda Rossela w oficjalnej wizycie państwowej w Niemczech kierowanej przez Władimira Putina (Kuznetsov, 2009). Rosyjskie Ministerstwo Spraw Zagranicznych od 2007 roku organizuje w Moskwie prezentacje regionów Rosji, obejmujące udostępnianie informacji na temat jego potencjału gospodarczego i naukowego, zasad polityki inwestycyjnej, istniejących sieci kontaktów gospodarczych z zagranicą i perspektywicznych projektów (Об участии, 2015).

Przykład Sankt-Petersburga po roku 2000 pokazuje natomiast, że region może mieć rozbudowaną sieć kontaktów gospodarczych i kulturalnych ze światem zewnętrznym, w tym także z Europa, jeśli tylko Kreml uznaje taką współpracę za korzystną dla Rosji jako całej i podejmuje działania na rzecz jej dalszego stymulowania. Sergunin i Joenniemi zwracaja uwage, że wbrew wypracowanemu jeszcze w latach 90. kompromisowi między Kremlem a regionami, na mocy którego podmioty Federacji Rosyjskiej będą zawierały porozumienia z partnerami o tym samym statusie, Sankt-Petersburg miał możliwość zawierania porozumień z państwami i ministerstwami, w tym m.in. z: Austria, Białorusia, Litwą, Tadżykistanem i Turkmenistanem w latach 2010-2012 (Joenniemi, Sergunin, 2014, s. 24). Przypadek aktywności międzynarodowej Sankt-Petersburga po roku 2000 dowodzi, że w warunkach zdecydowanie większej kontroli nad władzami regionalnymi ze strony centrum regiony zwracają baczną uwagę na oczekiwania i interesy Kremla w sferze polityki zagranicznej. „Wrażliwość” na oczekiwania Kremla w zakresie kierunków geograficznych i zasad wspótpracy regionu ze światem zewnętrznym (głównie Europa) przebija z dokumentów Petersburga poświęconych długofalowym założeniom rozwoju społeczno-gospodarczego. Innymi słowy Sankt-Petersburg może „pozwolić sobie na więcej” w sferze aktywności międzynarodowej, bowiem jego działania $\mathrm{w}$ tym zakresie korespondują z oczekiwaniami Kremla w polityce zagranicznej lub wręcz stanowią wyraz skoordynowanej polityki regionu i centrum (Reisinger, Yoo, 2012, s. 24).

Nie wszystkie regiony są w jednakowym stopniu poddane oddziaływaniu modelu scentralizowanej koordynacji, tzn. że nie są traktowane instrumentalnie i/lub „zachęcane” do współpracy międzynarodowej lub na przykład nie są na jego wpływ podatne. Relacje regionów z centrum 
w zakresie współpracy międzynarodowej po roku 2000 zależą od szeregu czynników. Są one związane ze znaczeniem regionu w systemie politycznym Rosji, pod względem politycznym i surowcowym, a także z uwarunkowaniami geopolitycznymi.

Zwraca uwagę fakt, że w dalszym ciagu istnieją podmioty Federacji Rosyjskiej, które w relacjach z centrum mogą pozwolić sobie na więcej, a ich liderzy są zdolni kontestować decyzję władz federalnych i ich agend w regionach (Czeczenia, Tatarstan). Część z regionów, jak chociażby Tatarstan, wciąż korzysta z dobrodziejstw politycznej i gospodarczej wyjątkowości i cieszy się daleko idącą autonomią, tak w relacjach wewnętrznych, jak i zewnętrznych w obrębie systemu stosunków federacyjnych. W przypadku Tatarstanu w grę wchodzi konsekwentny sprzeciw wobec zmiany nazwy osoby sprawującej najwyższy urząd w republice, tj. zaprzestania stosowania terminu prezydent, co stanowi jawne naruszenia norm ustawodawstwa federalnego. Co więcej, Tatarstan podtrzymuje bliskie stosunki gospodarcze z Turcją - wrogiem numer jeden Rosji od czasu zestrzelenia rosyjskiego samolotu szturmowego biorącego udział w operacji w Syrii. Prorosyjscy dziennikarze, jak Rais Sulejmanow krytykujący władze republikańskie: zarzucające im udzielanie wsparcia islamistom, rozszerzanie współpracy z Turcją i podejmowanie działań na rzecz dalszego usamodzielniania się od Rosji, spotykają się z prześladowaniami ze strony władz republiki (Whitmore, 2016).

Inne regiony m.in. północno-zachodniej Rosji, pozbawione są podobnych atutów, nie zamierzają jednak poddawać się bez walki i rezygnować z dotychczas wypracowanych kontaktów z partnerami zagranicznymi. Tym bardziej, że współpraca międzynarodowa w ich przypadku jest istotnym elementem prawidłowego funkcjonowania ich systemów społecznogospodarczych. Podobnie rzecz ma się z niektórymi regionami Dalekiego Wschodu, w przypadku których regiony chińskie są podstawowym partnerem gospodarczym, a dla ich mieszkańców głównym źródłem towarów powszechnego użytku, tj. na poziomie $60-70 \%$, co staje się zrozumiałe, biorąc pod uwagę, że składowa transportowa w ogólnej wartości towarów wynosi dla dalekowschodniego okręgu federalnego od 55 do $70 \%$ przy średniej rosyjskiej na poziomie 25\% (Зыков, 2016, s. 7-10).

Szereg autorów podejmujących problem współpracy międzynarodowej regionów Rosji po 2000 roku daje wyraz swojemu przeświadczeniu, że w trosce o zdobycie - kurczących się - zasobów koniecznych do podtrzymania źródeł wzrostu społeczno-gospodarczego, regiony (w szczególności peryferyjne) z jeszcze większym zainteresowaniem spoglądają 
w stronę współpracy międzynarodowej (Абдразакова, Курилла, 2011, s. 455). Regionalne elity polityczne w Rosji zachowują wciąż pewną część swobody, mimo zdecydowanych działań ze strony centrum na rzecz wtłoczenia ich w tzw. pionową strukturę władzy i podejmowanych od czasu do czasu głośnych „czystek” o podłożu antykorupcyjnym wśród korpusu gubernatorskiego. Abdrazkowa i Kuriłła piszą m.in., że oddziaływanie centrum na regiony, jeśli chodzi o ich aktywność międzynarodową, jest znikome - pomimo tego, że znalazły się one formalnie pod ścisłą kontrolą centrum federalnego. Regiony informują np. centrum federalne o swej działalności międzynarodowej post factum - raz na kwartał sporządzając raporty dla Ministerstwa Spraw Zagranicznych (Абдразакова, Курилла, 2011, s. 456).

Kontrola centrum nad regionami nie jest absolutna, Kreml nie jest władny zapanować nad procesami politycznymi dojrzewającymi w regionach co wiąże się chociażby z brakiem kompetentnych kadr, mogących równocześnie skutecznie realizować funkcje gubernatorskie i zagwarantować Kremlowi podczas wyborów federalnych i regionalnych wysoki poziom społecznego poparcia. Pozostaje także kwestia lojalności federalnych urzędników w regionach, która to lojalność jest podobnie jak w latach 90. stawiana pod znakiem zapytania. Część autorów zwraca uwagę, że przedstawiciele agend federalnych powinni nominalnie kontrolować i koordynować współpracę międzynarodową regionów. W praktyce agendy federalne $w$ regionach wykorzystywane są przez władze regionalne do wywierania dodatkowego wpływu na centrum, do czego walnie ma się przyczyniać uzależnienie wspomnianych urzędników od władz regionalnych w zakresie zakwaterowania i aprowizacji (Joenniemi, Sergunin, 2014, s. 27). Ponadto zatrudnienie w regionalnych agencjach rządu federalnego, znajdują ,autochtoni”, mający bliskie związki z lokalnymi elitami. W grę wchodzi więc nie tyle zjawisko korupcji, co raczej ziemliaczestwo i naturalna więź z przedstawicielami lokalnej wspólnoty politycznej i jej notablami.

\section{Konsekwencje polityki centrum federalnego w odniesieniu do aktywności międzynarodowej \\ z punktu widzenia regionów i ich interesów}

Warto zwrócić uwagę na zagadnienia geopolityczne i geoekonomiczne, które rodzą napięcie pomiędzy Kremlem a regionami i konsekwencje, 
jakie to napięcie generuje z punktu widzenia regionów podtrzymujących intensywne kontakty z zagranicą. Niekiedy centrum federalne daje zdecydowany wyraz swej dezaprobacie jeśli chodzi o współpracę regionów Rosji z wybranymi partnerami zewnętrznymi. Kreml może więc zachęcać regiony do współpracy z Chinami i uniemożliwiać rozwój współpracy z państwami członkowskimi Unii Europejskiej czy szerzej Zachodem. Napięcie pomiędzy interesami centrum i regionów może być postrzegane jako wypadkowa potrzeb i oczekiwań regionów i centrum, lub też jako dowód na funkcjonowanie obydwu grup podmiotów w dwóch różnych rzeczywistościach: odpowiednio regionalnej i globalnej. Kreml, rozgrywając globalną grę geopolityczną, krytykuje rozszerzenie NATO na Wschód czy izoluje się od towarów pochodzących z Zachodu. Dla przykładu rozszerzenie NATO wywołało więcej protestów w samej Moskwie niż w regionach graniczących z przyszłymi państwami członkowskimi NATO. Symptomatyczne dla analizowanej wcześniej „strategicznej kultury" federalnego kręgu elit politycznych było pełne negatywnych emocji stanowisko w odniesieniu do rozszerzania NATO na Wschód, przy jednoczesnym ignorowaniu rozszerzania EU, które w przyszłości miało mieć zdecydowanie poważniejsze konsekwencje z punktu widzenia interesów Rosji niż włączenie do NATO Polski i państw bałtyckich.

Napięcie pomiędzy geopolitycznymi i geoekonomicznymi preferencjami Kremla a interesami społeczno-gospodarczymi regionów było i w dalszym ciągu jest świetnie widoczne na przykładzie regionów północno-zachodnich ze szczególnym uwzględnieniem obwodu kaliningradzkiego. Region jako enklawa, skrajnie oddalona od Moskwy w kierunku zachodnim w 70\% uzależniony jest od dostaw wyrobów mlecznych z Europy, w 50\% od owoców i warzyw, a także w 40\% od drobiu. Embargo na produkty z UE, Norwegii, Australii, Kanady i Stanów Zjednoczonych spowodowało, że ceny na te produkty podwoiły się -musiały być sprowadzane z innych regionów Rosji. Gubernator obwodu próbował - jednak bez skutku - przekonać władze federalne do zniesienia lub co najmniej złagodzenia embarga. Również sami przedsiębiorcy trudniący się importem żywności zwrócili się o pomoc do rosyjskiego rządu - nie została im ona udzielona. W ostateczności zaczęto uciekać się do niezgodnych z prawem form obchodzenia embarga przy oczywistej i cichej aprobacie ze strony władz regionalnych (Golunov, 2015).

Regiony, które są zainteresowane współpracą międzynarodową (a w szczególności jednostki samorządu terytorialnego) bez wsparcia Kremla nie odniosą jakichkolwiek sukcesów na tym polu lub w ogóle 
takiej współpracy nie podejmą. O ile regiony nie są w stanie szkodzić interesom centrum federalnego - istnieje cały szereg mechanizmów prawnych i politycznych, które sprowadzają do zera szanse pojawienia się takiego zagrożenia - o tyle polityka centrum federalnego może szkodzić interesom regionów. Szkodzą im nie tylko, jak ma to miejsce w przypadku Dalekiego Wschodu, błędy w planowaniu strategicznym, brak gotowości do wprowadzenia ulg transportowych, urawniłowka w podejściu do ich zróżnicowania, czy w końcu kolonialne podejście do dalekowschodniej rubieży Rosji polegające na jej eksploatacji połączonej z brakiem inwestycji (Зыков, 2016, s. 9-10).

Andriej Makaryczew wspomina w kontekście wysiłków regionów północno-zachodniej Rosji na rzecz rozwoju współpracy międzynarodowej o zniechęcaniu przez władze federalne obwodu kaliningradzkiego do udziału w pracach euroregionu Niemen. Joennimi i Sergunin wskazują na kilka przykładów zablokowania niezwykle interesujących inicjatyw w północno-zachodniej Rosji z udziałem obwodu murmańskiego i Karelii. Kreml ,zatopił” projekt stworzenia parku przemysłowego na granicy rosyjsko-fińskiej pomiędzy Imatrą a Swietogorskiem, jak również utworzenie specjalnej strefy ekonomicznej Pomor na granicy norwesko-rosyjskiej z udziałem obwodu murmańskiego i gminy Sør Varanger (Joenniemi, Sergunin, 2014, s. 22).

Jak można się było spodziewać regiony najbardziej zainteresowane współpracą z państwami Europy Zachodniej i Północnej, najmocniej też krytykowały politykę centrum federalnego, a ich władze próbowały interweniować na rzecz zabezpieczenia interesów lokalnych społeczności i podmiotów gospodarczych, co udowodnił przypadek obwodu kaliningradzkiego. Regiony zaczęły manifestować swój brak zadowolenia i zaufania do decyzji centrum. Zwracano uwagę, że skrajnie scentralizowany i uniwersalny model relacji centrum-regiony nie powinien rozciagać się na obszar aktywności międzynarodowej regionów, jako, że takie podejście jest wyjątkowo nieelastyczne i nieefektywne. Centrum federalne powinno też, zdaniem regionów, przewartościować swoje podejście do ,paradyplomacji” regionów, tak by właściwie reagować na wyzwania społeczno-gospodarcze stające przed regionami, a także zrozumieć i umieć dopasować się do zjawiska glokalizacji. To centrum powinno dostosować się do potrzeb regionów i adekwatnie reagować na ich potrzeby (Joenniemi, Sergunin, 2014, s. 30). Z Dalekiego Wschodu napływały natomiast głosy, że interesy regionów mają charakter ekonomiczny nie zaś polityczny, jeśli chodzi o współpracę międzynarodową. Nie stanowią za- 
grożenia dla interesów narodowych Rosji, a wręcz przeciwnie - sprzyjają ich zabezpieczaniu, rozładowaniu ulegają napięcia społeczne o podłożu materialnym, dzięki współpracy międzynarodowej (Зыков, 2016, s. 5).

\section{Podsumowanie}

Podsumowując rozważania na temat instytucjonalizacji szczególnego modelu relacji centrum-regiony w wymiarze współpracy międzynarodowej rosyjskich regionów po 1999 roku toczącej się na tle ewolucji rosyjskiego federalizmu, godzi się przywołać kilka najistotniejszych obserwacji, które pozwolą podsumować i uzupełnić wnioski sformułowane w artykule.

Przede wszystkim, podejście centrum federalnego do autonomii, w tym także aktywności międzynarodowej podmiotów składowych Federacji Rosyjskiej, prowadzące do budowy modelu scentralizowanej koordynacji, może być rozpatrywane przez pryzmat istniejących teorii z zakresu stosunków międzynarodowych. W takim ujęciu kształtowanie się rzeczonego modelu relacji centrum-regiony jest przykładem „triumfu” szkoły realistycznej w Rosji po roku 1999. Obecność realizmu w przypadku analizowanego problemu, tj. stosunku Kremla do aktywności międzynarodowej regionów Rosji daje o sobie znać w każdym z analizowanych aspektów zjawiska, tak na poziomie konceptualnym (w zakresie wizji miejsca i roli regionów w strategii rozwoju polityki zagranicznej Rosji), jak i praktycznym (mowa tu o sposobie wykorzystania regionów i ich kontaktów międzynarodowych przez centrum do promocji interesów narodowych Rosji).

Charakter rosyjskiego systemu politycznego koresponduje z charakterem stosunków centrum-regiony: jelcynowski czas anokracji korespondował $\mathrm{z}$ asymetrycznym federalizmem, putinowski wyborczy autorytaryzm harmonijnie współgra $z$ unitarnym federalizmem. Podobnie rzecz ma się z modelem aktywności międzynarodowej regionów, przed rokiem 2000 dominował model zdecentralizowany, po roku 2000 konsolidacji ulega model scentralizowany. Autorytarny charakter systemu politycznego Rosji (a nie szeregu jej regionów) nie stał w latach 90., ani nie stoi w chwili obecnej, na przeszkodzie rozwoju aktywności międzynarodowej regionów.

Rosyjskie regiony dysponują wskutek urzeczywistnienia koncepcji centralizacji stosunków federacyjnych (defederalizacji) znacznie mniej- 
szym zakresem autonomii w procesie decyzyjnym. Regionalne elity polityczne poddane zostały politycznej presji ze strony Kremla - zostały „wciśnięte w gorset” pionowej struktury władzy i funkcjonują w ramach sztywnych ram instytucjonalno-prawnych, jeśli chodzi o ich udział w międzynarodowej wymianie gospodarczej i współpracy międzynarodowej. Centrum federalne przejawia otwartą skłonność do instrumentalnego wykorzystywania regionów w procesie urzeczywistniania swych celów w polityce zagranicznej, niekiedy jednak ku obopólnej korzyści.

Elity federalne pod rządami Władimira Putina mimo formalnego podporządkowania regionów centrum wciąż z (irracjonalną) podejrzliwością spoglądają na elity regionalne, upatrując w nich zagrożenia dla swej dominacji $\mathrm{w}$ systemie politycznym, czy wręcz $\mathrm{w}$ obawie przed wzmacnianiem tendencji separatystycznych. Czynią tak zarówno pod wpływem doświadczeń lat 90. kiedy to działania części regionów doprowadziły do rozpadu jednolitej przestrzeni polityczno-prawnej Federacji Rosyjskiej, a także z powodu specyficznego podejścia do koncepcji suwerenności ukształtowanej tak przez wspomniane doświadczenia wewnątrzpolityczne, jak również przez ,politykę ekspansji na Wschód” zachodnioeuropejskich struktur polityczno-gospodarczych (UE) i polityczno-militarnych (NATO), oraz penetracji obszaru poradzieckiego przez Stany Zjednoczone (Plan Działań na Rzecz Członkostwa w NATO) i Unię Europejską (Partnerstwo Wschodnie). Centralizacji stosunków federacyjnych w wymiarze prawnym i politycznym towarzyszył rozwijający się stopniowo acz zdecydowanie anty-zachodni wektor w polityce zagranicznej Rosji, zaś elitę federalną Rosji, sukcesywnie zasilały osoby, które reprezentowały szczególny typ „strategicznego myślenia”, afirmującego idee niepodzielnej suwerenności państwa narodowego, postrzegające globalizację/ glokalizację jako źródło zagrożenie dla interesów narodowych Rosji, czy wręcz bezpieczeństwa narodowego, doszukujące się złych intencji u aktorów angażujących się we współpracę z regionami.

Mimo ogromnej przewagi centrum nad regionami pod względem dostępnych zasobów i wskutek ustanowionych reguł formalno-prawnych funkcjonowania stosunków federacyjnych, elity regionalne pozostają siłą, z którą władze centrum muszą się liczyć tak w wymiarze negatywnym (sabotowanie polityki centrum/nieumiejętne wcielanie jej w życie), jak i pozytywnym (mobilizacja ,zaplecza administracyjnego" podczas kluczowych dla Kremla kampanii wyborczych). Częśc najsilniejszych regionów wykorzystuje tę sytuację na swoją korzyść, inne, pozbawione atutów politycznych i gospodarczych, lecz mających pozytywne do- 
świadczenia współpracy z państwami Zachodu w latach 90., starają się ze wszelkich sił bronić swej autonomii. Wszystko to powoduje, że model scentralizowanej koordynacji nie jest wewnętrznie spójny i tym samym skonsolidowany.

Spoglądając wstecz na zagadnienie aktywności międzynarodowej regionów Rosji po 2000 roku, pod kątem jej wpływu na rosyjską państwowość, zaniepokojenie budzi fakt, że model scentralizowanej koordynacji działań regionów może być w niektórych przypadkach skrajnie niekorzystny dla regionów. W szerszej perspektywie jego konsolidacja stanowić może wyzwanie dla stabilności rosyjskiego systemu politycznego w obecnym kształcie, generuje bowiem nastroje niezadowolenia i protestu w regionach najbardziej zainteresowanych współpracą międzynarodową - która jest dla nich jednym z istotnych źródeł rozwoju społeczno-gospodarczego. Wymuszane przez Kreml formy współpracy międzynarodowej nie przynoszą bowiem spodziewanych skutków. Doświadczenie aktywności międzynarodowej regionów rosyjskiego Dalekiego Wschodu, czy szerzej także współpracy gospodarczej Rosja-Chiny, która miała zastąpić kontakty gospodarcze Rosji z Zachodem po roku 2014, są tego najlepszym przykładem (Коростиков, 2016, s. 9).

Jeśli więc doświadczenie lat 90. w zakresie aktywności międzynarodowej regionów umacniały poczucie konieczności uporządkowania relacji centrum-regiony dla dobra rozwoju rosyjskiej państwowości, to „owoce” współpracy międzynarodowej będące udziałem regionów Rosji po 2000 roku dowodzą, że centralizacja stosunków federacyjnych jawnie szkodzi rosyjskiej państwowości, zarówno wizerunkowi międzynarodowemu Rosji, interesom podmiotów gospodarczych, zwykłym obywatelom, a nawet stabilności systemu autorytarnego zbudowanego wokół osoby Władimira Putina.

\section{Bibliografia}

Alexandrov O. (2001), The City of Moscow in Russia's Foreign and Security Policy. Role, Aims and Motivations, Working Paper No. 7, Center for Security Studies (CSS), ETH Zurich.

Ambrosio T. (2009), Authoritarian Backlash: Russian Resistance to Democratization in the Former Soviet Union, Ashgate, Abingdon, Oxon.

Whitmore B. (2016), What Do Tatarstan And Belarus Have In Common?, „Radio Free Europe/Radio Liberty", 14.01.2016, http://www.rferl.org/content/whatdo-tatarstan-and-belarus-have-in-common/27487602.html, 12.03.2016. 
Chirikova A., Lapina N. (2001), Regional Elite. A Quiet Revolution on a Russian Scale, Working Paper No. 4, Center for Security Studies (CSS), ETH Zurich.

Europejska konwencja ramowa o wspótpracy transgranicznej między wspólnotami $i$ władzami terytorialnymi, sporzadzona w Madrycie dnia 21 maja 1980 r., http://isap.sejm.gov.pl/DetailsServlet?id=WDU19930610287, 12.03.2016.

Every Village With Its Own Foreign Ministry? (1999), „RFE/RL Russia Report”, 31.03.1999, http://www.rferl.org/content/article/1344562.html, 12.03.2016.

Sharafutdinova G. (2005), Opportunities and Limits of Self-Creation and Identity Politics: Tatarstan's Paradiplomatic Project, w: Emerging Meso-Areas in the Former Socialist Countries, Histories Revived or Improvised? (Slavic Eurasian Studies, no. 7), red. K. Matsuzato, Hokkaido.

Makarov I., Barabanov O., Bordachev T., Kanaev E., Larin V., Ryzhkov V. (2014), Toward the Great Ocean - 2, or Russia's Breakthrough to Asia, Valdai Discussion Club Report Moscow, http://vid-1.rian.ru/ig/valdai/Twd_Great Ocean_2_Eng.pdf, 12.03.2016.

Joenniemi P., Sergunin A. (2014), Paradiplomacy as a Capacity-Building Strategy, The Case of Russia's Northwestern Subnational Actors, „Problems of PostCommunism", vol. 61, no. 6.

Kurilla I. I. (2006), Russian Regions and International Systems A Trajectory of PostSoviet Interaction, „PONARS Policy Memo”, no. 422, http://csis.org/files/ media/csis/pubs/pm_0422.pdf, 12.03.2016.

Kuznetsov A. (2015), Theory and Pratice of Paradiplomacy. Subnational governments in international affairs, Routledge.

Kuznetsov A. (2009), Paradiplomacy as the Domestic Source of Russian Foreign Policy An Analysis on the basis of theoretical framework Paper Prepared for the $50^{\text {th }}$ Annual International Studies Association Meeting New York, February 15-18, 2009, http://citation.allacademic.com/meta/p_mla_apa_research_citation/3/1/1/7/5/pages311753/p311753-1.php, 7.03.2016.

Leichtova M. (2014), Misunderstanding Russia Russian Foreign Policy and the West, Ashgate Publishing.

Lo B. (2002), Russian Foreign Policy in the Post-Soviet Era. Reality, Illusion and Mythmaking, Macmillan, Palgrave.

Makarychev A. (2000), Islands of Globalization. Regional Russia and the Outside World, Working Paper No. 2, Center for Security Studies (CSS), ETH Zurich.

Makarychev A. (1999), Russian Regions as International Actors, „Demokratizatsiya”, vol. 7 , no. 4 .

Perović J. (2000), Internationalization of Russian Regions and the Consequences for Russian Foreign and Security Policy, Working Paper no. 1, Center for Security Studies (CSS), ETH Zurich.

Raś M. (2013), Regiony Federacji Rosyjskiej w stosunkach międzynarodowych, w: Poziomy analizy stosunków międzynarodowych, t. I, red. E. Haliżak, M. Pietraś, Warszawa. 
Reisinger W., Yoo H. (2012), Russian Regional Foreign Policy Looking East And West, Prepared for presentation at the $53^{\text {rd }}$ Annual Convention of the International Studies Association San Diego, CA, April 1-4, 2012, http://ir.uiowa. edu/cgi/viewcontent.cgi?article=1101\&context=polisci_pubs, 7.03.2016.

Rychlik J. (2014), Wybrane zagadnienia działalności międzynarodowej podmiotów Federacji Rosyjskiej, „Przegląd Prawa Konstytucyjnego”, nr 2 (18).

Golunov S. (2015), Torn Between Patriotism and Economic Necessities: Russia's EU Borderlands after the Food Embargo, „PONARS Eurasia Policy Memos”, no. 360, http://www.ponarseurasia.org/memo/torn-between-patriotism-andeconomic-necessities, 12.03.2016.

Абдразакова Э., Курилла И. (2011), Внешняя политика и международные связи регионов, w: Россия „двухтысячных”: стереоскопический взгляд, red. Г. Хейл, И Курилла, Москва.

Бусыгина И., Лебедева Е. (2008), Субъекть федерации в международном сотрудничестве, „Аналитические Записки, Научно-координационного совета по международным исследованиям", МГИМО (У) МИД России, Выпуск 3(32).

Неяскин Г. (2015), Шесть карт, которые объясняют Россию, 30.10.2015, https:// slon.ru/posts/58717, 12.03.2016.

Доклад Совета Федераџии Федерального Собрания Российской Федерации 2009 Года. О состоянии законодательства в Российской Федерации. Мониторинг правового обеспечения основных направлений внутренней и внешней политики (2010), Москва, http:/council.gov.ru/media/ files/41d44f244098908a7989.pdf, 7.03.2016.

Захаров А. (2008), Унитарная федерация. Пять этюдов о российском федерализме, Москва.

Зыков А. А. (2016), Интеграционные перспективы и возможности стратегического развития Дальнего Востока России, http://www.idmrr.ru/downloads/ konkurs/Zikov.doc, 25.02.2016.

Информация о ходе реализачии Программы сотрудничества между регионами Дальнего Востока и Восточной Сибири РФ и Северо-Востока КНР (2009-2018 годы) в 2014 году, Ассоииация экономического взаимодействия субъектов Российской Федерации „Дальний Восток и Забайкалье” (2014), http://assoc.khv.gov.ru/regions/foreign-economic-activities/ russian-chinese-cooperation-program-monitoring/788, 7.03.2016.

Концеепии работы МИД России по координации международных и внешнеэкономических связей субъектов Российской Федерации. Утверждена на заседании Коллегии МИД России 13 июня 2001 года, http://archive.mid. ru//bdomp/sbor.nsf/fe3845c0f6d9b35443256c8a004e8835/6e5367d4d98d2f7 a43256c8a0047bc48! OpenDocument, 7.03.2016.

Коростиков М. (2016), Уроки китайского. Почему за прошедший год России не вполне удался ,, поворот на Восток”, „Коммерсанть Власть”, 8.02.2016.

Макарычев А. С. (2001), Российские регионы и глобализащия, Нижний Новгород, 10.03.2016, http://www.policy.hu/makarychev/rus21.htm, 12.03.2016. 
Международные и внешнеэкономические связи субъектов Российской Федерации, http://archive.mid.ru//bdomp/sitemap.nsf/kartaflat/03.02.02.07, 12.03.2016.

Намчак С. А. (2012), Регионы Российской Федерации как субъект международных отношений, „Новые исследования Тувы”, № 1.

Никольская П., Романычева А. (2015), Судьба агента. С начала 2015 года в России признали иностранными агентами десятки некоммерческих организациий, „Коммерсанть Власть”, 18.05.2015.

Об участии Министра иностранных дел России С. В. Лаврова в презентации Новосибирской области (2015), http://www.mid.ru/foreign_policy/news/-/ asset publisher/cKNonkJE02Bw/content/id/1937988, 12.03.2016.

Положение о территориальном органе - Представительстве Министерства иностранных дел Российской Федерации на территории Российской Федерации (2011), Приложение №1 к Приказу МИД Россииот, 22 ноября 2011 г., № 21341, http://www.mid.ru/activity/shots/service/law_on_service/-/ asset_publisher/s6NLVAIqZ3pG/content/id/158530, 12.03.2016.

Программа сотрудничества между регионами Дальнего Востока и Восточной Сибири Российской Федераџии и Северо-Востока Китайской Народной Республики (2009-2018 годы) (2008), http://www.kp.ru/f/13/attached file/91/92/559291.doc, 12.03.2016.

Российско-китайский диалог: модель 2015 (2015), № 18, Российский совет по международным делам, Институт Дальнего Востока РАН, Институт международных исследований Фуданьского университета, Москва, http://russiancouncil.ru/common/upload/RIAC_Russia_China_Report.pdf, 12.03.2016.

Стародубровская И., Глазычев В. (2011), Федерализм истинный и мнимый, Статья является фрагментом доклада „Стратегия-2020: Новая модель роста - новая сочиальная политика", подготовленного группой российских экспертов, „Московские новости”, 14.09.2011.

Туровский Р. (2011), Субнациональные регионы в глобальной политике (на примере России), „Полис. Политические исследования”, № 2.

\section{The Russian Federation's approach to the international activities of regions through the prism of the evolution of federal-regional relations}

\section{Summary}

The paper's aim is to explore the federal-regional model of relations as far as international activities of regions is concerned. A persistent centralization tendency, applied to the federal-regional model of relations and started under Vladimir Putin's presidency, has created an unusual concept of centralist coordination concerning the international activity of regions. Despite the federal dominance over regions, the con- 
cept is far from being consolidated, since the Kremlin lacks the resources, mainly human, to fully control the political situation in the regions. Yet, this evolving centralist concept seems to be detrimental not only to regions' interest, but also questions the strength of Putin's model of an authoritarian regime in the long term.

Key words: centre-regions, Russia, centralization, Russian political system 
